\title{
PLACE OF SOCIAL RESPONSIBILITY IN PROJECT MANAGEMENT
}

\author{
Karolina WIELICKA-GAŃCZARCZYK \\ Silesian University, Department of Management and Organization; Karolina.Wielicka-Ganczarczyk@polsl.pl, \\ ORCID: 0000-0001-5475-6661
}

Purpose: the aim of this article is to identify the place of social responsibility in the area of project management. The article is aims to determine the areas of interpenetration or mutual relations between Corporate Social Responsibility (CSR) and Project Management (PM).

Design/methodology/approach: this paper reviewed different definitions of Corporate Social Responsibility (CSR), project and project management. The article is an attempt to systematise the relatively new concept of Project Social Responsibility (PSR), which requires combining the CSR concept with a project approach. Since each company, apart from its current activity, carries out or will carry out projects in the future, the aim of this article is to identify the place of social responsibility in the area of project management. The article is of an analytical nature. Findings: none of the mentioned definitions of project management or the project itself referred to the company's strategy, social, environmental or even stakeholder impact. Moreover, stakeholders are one of the main reasons for the implementation of projects.

Originality/value: the comparison made between 'CSR' and the term 'portfolio management' already indicates a greater correlation between these concepts. It may therefore be assumed that the place of Corporate Social Responsibility is in the portfolio management and involves planning and implementation of current activities, programmes or projects relevant to the company's strategic objectives and taking into account their impact, as well as the impact of the company itself on CSR areas.

Keywords: corporate social responsibility, project management, social project management.

Category of the paper: viewpoint.

\section{Introduction}

Project Social Responsibility (PSR) is a relatively unknown concept, as can be illustrated by the number of references to this concept in the Google search engine, which is just 102,000 results. By comparison, when typing "project management", there are already 232 million results. In scientific databases such as BazTech, BazEkon, Elsevier - Science Direct the subject of PSR is not widely known either (the number of found scientific articles referring to the social responsibility of projects was respectively: $1,0,14$ ). 
Many definitions of Corporate Social Responsibility emphasise that it is a management strategy of some kind, for the implementation of which experts are appointed to the positions of CSR manager (otherwise it will be a person responsible for projects implemented in the area of CSR). Frequently, CSR is misunderstood by entrepreneurs and treated as a concept referring only to the public or non-profit sector, which in itself performs activities in this area. Others, in turn, consider CSR a kind of compulsion (given the need to include non-financial areas in financial reports) or a marketing tool (Tylec A., 2016, p. 514) aimed at improving the company image.

\section{Corporate Social Responsibility (CSR)}

In the literature on the subject, CSR is used interchangeably with the terms - "Corporate Social Performance" (Goergen et al., 2019, p. 123), "Sustainability Management" (Levytska, Wrzesińska-Kowal, 2013, p. 171), or "Socially Engaged Enterprise" (Buczkowski et al., 2016, p. 13). In scientific publications available in the Internet (number of articles $n=60$, keywords: csr, corporate social responsibility) the definitions that originated between 1953 and 2011 prevail $(\mathrm{H}$. Bowen, considered the founding father of CSR, attempted to define this concept in 1953 in his book entitled "Social Responsibilities of the Businessman"). This is also confirmed by research carried out by other scientists (Leoński, 2016), (Hamidu et al., 2015, p. 83-85), (Dahlsrud, 2006; Pisani et al., 2017; Rong-Jia SU, Xiao-Wen JIE, 2015). The concept of CSR was changing over the course of many years, originally it was based on voluntary charity (philanthropic activity), then through the encyclical of Leo XIII it referred to personal responsibility defined as prevention (foresight), and gained in significance as late as in the 1990s (Buczkowski et al., 2016, p. 11). Nowadays, two main approaches to CSR prevail in the literature on the subject, one of them emphasises the voluntary application of the CSR concept (Klimek, 2014, p. 270), while the second one focuses on the company management strategy, of which CSR is an essential element (Misztal, 2016, p. 75). One of the most frequently mentioned (Czubała, 2016, p. 104) and the broadest definition of CSR was included in the ISO 26000 standard (ISO 26000, Rojek-Nowosielska, 2017), which states that social responsibility is "the responsibility of an organisation for the impacts of its decisions and activities on society and the environment, through transparent and ethical behaviour that:

- contributes to sustainable development, including health and the welfare of society,

- takes into account the expectations of stakeholders,

- is in compliance with applicable laws and consistent with international norms of behaviour,

- is integrated throughout the organisation and practiced in its relationships". 
The definition mentioned previously describes both the areas of SCR concentration (society, environment, stakeholders) and also shows the company's correlation with sustainable development, and therefore does not consider these concepts as being interchangeable. The aforementioned definition does not contain a provision that explicitly indicates the voluntary application of the CSR concept. It results from the fact that the standard itself is not subject to accreditation, and hence its application is voluntary (Różańska, 2015, p. 173).

Apart from scientific studies, the definitions of CSR are included, among others, in reports on Corporate Social Responsibility, on the websites of governmental, non-governmental, public and commercial organisations, also some elements of CSR are visible in legal regulations. Tables 1 and 2 present the approach of Polish and foreign organisations to CSR.

Table 1.

Selected CSR definitions according to Polish organisations

\begin{tabular}{|c|c|c|c|}
\hline Source & $\begin{array}{l}\text { Organisation } \\
\text { type }\end{array}$ & CSR definition & $\begin{array}{l}\text { Concentration } \\
\text { area in CSR }\end{array}$ \\
\hline $\begin{array}{l}\text { Ministry of Investment } \\
\text { and Economic } \\
\text { Development }\end{array}$ & $\begin{array}{l}\text { Public - } \\
\text { government } \\
\text { administration }\end{array}$ & $\begin{array}{l}\text { the definition adopted following the European } \\
\text { Commission, i.e. "the responsibility of } \\
\text { enterprises for their impact on society". }\end{array}$ & 1. Society \\
\hline $\begin{array}{l}\text { Department of Social } \\
\text { and Solidarity } \\
\text { Economy in the } \\
\text { Ministry of Family, } \\
\text { Labour and Social } \\
\text { Policy }\end{array}$ & $\begin{array}{l}\text { Public - } \\
\text { government } \\
\text { administration }\end{array}$ & $\begin{array}{l}\text { "a concept whereby companies integrate social } \\
\text { and environmental concerns in their business } \\
\text { operations and in their interaction with their } \\
\text { stakeholders on a voluntary basis". }\end{array}$ & $\begin{array}{l}\text { 1. Management } \\
\text { strategy } \\
\text { 2. Society } \\
\text { 3. Natural } \\
\text { environment } \\
\text { 4. Stakeholders }\end{array}$ \\
\hline $\begin{array}{l}\text { Polish Agency for } \\
\text { Enterprise } \\
\text { Development (listed } \\
\text { company) }\end{array}$ & $\begin{array}{l}\text { Public - } \\
\text { government } \\
\text { administration } \\
\text { (the state as a } \\
\text { legal entity) }\end{array}$ & $\begin{array}{l}\text { "a management strategy whereby companies } \\
\text { integrate social and environmental concerns or } \\
\text { relations with different stakeholder groups, in } \\
\text { particular employees, into their operations on a } \\
\text { voluntary basis". }\end{array}$ & $\begin{array}{l}\text { 1. Management } \\
\text { strategy } \\
\text { 2. Society } \\
\text { 3. Natural } \\
\text { environment } \\
\text { 4. Stakeholders }\end{array}$ \\
\hline $\begin{array}{l}\text { The Responsible } \\
\text { Business Forum }\end{array}$ & $\begin{array}{l}\text { Non- } \\
\text { governmental } \\
\text { organisation }\end{array}$ & $\begin{array}{l}\text { "the responsibility of enterprises for their } \\
\text { impact on society". }\end{array}$ & 1. Society \\
\hline $\begin{array}{l}\text { PGE Group (listed } \\
\text { company) }\end{array}$ & $\begin{array}{l}\text { State-owned } \\
\text { company }\end{array}$ & $\begin{array}{l}\text { "combining the assurance of shareholder value } \\
\text { growth, energy security for customers and the } \\
\text { employment stability with care for the social } \\
\text { and natural environment". }\end{array}$ & $\begin{array}{l}\text { 1. Stakeholders } \\
\text { 2. Society } \\
\text { 3. Natural } \\
\text { environment }\end{array}$ \\
\hline $\begin{array}{l}\text { Polpharma } \\
\text { Pharmaceutical Works } \\
\text { (listed company) }\end{array}$ & $\begin{array}{l}\text { Private } \\
\text { company }\end{array}$ & $\begin{array}{l}\text { an answer to the question of how to "respond } \\
\text { even better to the needs of the stakeholders and } \\
\text { expand the business activities based on the } \\
\text { value system". }\end{array}$ & 1. Stakeholders \\
\hline $\begin{array}{l}\text { Bakoma (limited } \\
\text { company) }\end{array}$ & $\begin{array}{l}\text { Private } \\
\text { company }\end{array}$ & $\begin{array}{l}\text { a voluntary commitment to actively create } \\
\text { good relations with our broadly defined } \\
\text { environment. We are seeking solutions that are } \\
\text { beneficial to our company as well as to the } \\
\text { entire environment - employees, suppliers, } \\
\text { stakeholders, local communities and the } \\
\text { environment. }\end{array}$ & $\begin{array}{l}\text { 1. Stakeholders } \\
\text { 2. Society } \\
\text { 3. Natural } \\
\text { environment }\end{array}$ \\
\hline
\end{tabular}

Source: own elaboration based on www.ekonomiaspoleczna.gov.pl, www.parp.gov.pl, www. odpowiedzialnybiznes.pl, www.gkpge.pl, www.polpharma.pl, www.bakoma.pl 
Government organisations define CSR as an element of a business strategy that takes into consideration first the interests of society, then the environment and finally the stakeholders. In contrast, commercial companies approach CSR issues, which are first focused on the interests of their stakeholders, then society, and finally the environment.

In the Polish law, the concept of CSR is visible in the Economic Freedom Act of 2 July 2004 (Journal of Laws 2004, No. 173, item 1807), which states that:

- Article 17 - "an entrepreneur shall carry out the business activity on the basis of fair competition and respect for good manners and legitimate interests of consumers",

- Article 18 - "an entrepreneur is obliged to meet the conditions for carrying out business activity specified by law, in particular concerning protection against threats to human life, health and public morals, as well as environmental protection".

The concept of CSR is demonstrated primarily by reference to ethics/fairness, taking care of consumers (stakeholders) and the environment. In the European Union, CSR is already legally standardised through the Directive of the European Parliament and of the Council of 22 October 2014, which obliges public organisations employing more than 500 people to include information on social, labour and environmental issues in their activity reports (Directive..., 2014). Meanwhile, for instance, U.S. Department of State (during Barack Obama's presidency) uses the term Responsible Business Conduct (RBC) on its website, which is defined as "a broad concept based on the idea that businesses can perform well while doing good and that governments should set and facilitate the conditions for RBC to take place. The concept places particular importance on two aspects of the business-society relationship: (1) emphasising and accentuating the positive contributions businesses can make to economic, environmental, and social progress; and (2) recognising and avoiding possible adverse impacts of business conduct, as well as addressing them when they occur". The definition adopted by the U.S. Government clearly shows the influence of the state on business and businesses on economic progress, the environment and social development. The approach of foreign government organisations and commercial companies to CSR is presented below (Table 2).

Table 2.

Selected CSR definitions according to foreign organisations and authors

\begin{tabular}{|c|c|l|c|}
\hline Source & Organisation type & CSR definition & $\begin{array}{c}\text { Concentration } \\
\text { area in CSR }\end{array}$ \\
\hline $\begin{array}{c}\text { European } \\
\text { Commission }\end{array}$ & $\begin{array}{c}\text { Public - government } \\
\text { administration (EU } \\
\text { executive arm) }\end{array}$ & $\begin{array}{l}\text { "CSR: the responsibility of enterprises for their } \\
\text { impact on society and, therefore, it should be } \\
\text { company led" }\end{array}$ & 1. Society \\
\hline $\begin{array}{c}\text { Government } \\
\text { of Canada }\end{array}$ & $\begin{array}{c}\text { Public - government } \\
\text { administration }\end{array}$ & $\begin{array}{l}\text { "voluntary activities undertaken by a company, } \\
\text { over and above legal requirements, to operate in } \\
\text { an economically, socially and environmentally } \\
\text { sustainable manner" }\end{array}$ & 1. Sustainability \\
\hline
\end{tabular}


Cont. table 2.

\begin{tabular}{|c|c|c|c|}
\hline $\begin{array}{l}\text { Norwegian } \\
\text { Government } \\
\text { Security and } \\
\text { Service } \\
\text { Organisation }\end{array}$ & $\begin{array}{l}\text { Public - government } \\
\text { administration }\end{array}$ & $\begin{array}{l}\text { "businesses are expected to assume responsibility } \\
\text { for their impact on people, the environment, and } \\
\text { the communities and societies in which they } \\
\text { operate" }\end{array}$ & $\begin{array}{l}\text { 1. People (staff) } \\
\text { 2. Natural } \\
\text { environment } \\
\text { 3. Communities } \\
\text { 4. Society }\end{array}$ \\
\hline $\begin{array}{c}\text { World } \\
\text { Business } \\
\text { Council for } \\
\text { Sustainable } \\
\text { Development }\end{array}$ & $\begin{array}{l}\text { Non-governmental - } \\
\text { global association }\end{array}$ & $\begin{array}{l}\text { "safeguard the well-being of staff as well as the } \\
\text { ecosystems, communities, and economies in which } \\
\text { we work" }\end{array}$ & $\begin{array}{l}\text { 1. Staff } \\
\text { 2. Natural } \\
\text { environment } \\
\text { 3. Society } \\
\text { 4. Economies }\end{array}$ \\
\hline Google & $\begin{array}{l}\text { Private (limited } \\
\text { liability company) }\end{array}$ & $\begin{array}{l}\text { CSR as a tool to build sustainability into } \\
\text { everything what company does }\end{array}$ & 1. Sustainability \\
\hline BMW Group & $\begin{array}{l}\text { Private (public limited } \\
\text { company - AG) }\end{array}$ & $\begin{array}{l}\text { "integral part of its sustainable development } \\
\text { strategy, and in turn achieves the joint sustainable } \\
\text { development of corporate, society and the } \\
\text { environment" }\end{array}$ & $\begin{array}{l}\text { 1. Sustainability } \\
\text { 2. Society } \\
\text { 3. Natural } \\
\text { environment }\end{array}$ \\
\hline Cisco & Private (incorporated) & $\begin{array}{l}\text { initiatives that increase the results and solve global } \\
\text { problems }\end{array}$ & $\begin{array}{l}\text { 1. Company } \\
\text { results } \\
\text { 2. Global } \\
\text { problems }\end{array}$ \\
\hline
\end{tabular}

Source: own elaboration based on www.wbcsd.org, www.international.gc.ca, www.regjeringen.no, www.sustainability.google/.

Based on the adopted state policy, government organisations emphasise different areas of CSR, for instance, according to the European Commission, companies from EU countries should take into account the social interest in their activities, with Norwegian companies emphasising their employees, then the environment and local community. Among foreign companies with global presence, the most significant is the concern for sustainable development, i.e. "striving to achieve the best possible economic result while respecting the natural environment and social development". (Latoszek et al., 2016, p. 7), however, in Polish commercial companies what is most essential is to ensure stakeholders' satisfaction.

\section{Project management}

According to J. Nicholas and H. Steyn, as recently as about fifty years ago, project management was limited to the military industry (e.g. in defence, aviation or aerospace) and used in construction. Nowadays, it is one of the main areas of business activity, where the emphasis is put on increasing the effectiveness of implemented projects (Spałek, 2016, p. 4). It is estimated that with the further development of industry 4.0, where the emphasis is on digitisation, project management will become even more crucial for entrepreneurs (Spałek, 2017, p. 109). 
In the scientific output, project management is a subject that is widely covered and constantly subject to new research. In the Elsevier - Science Direct database alone, there are nearly 3,000 articles devoted to this topic, of which the most (165) were published in 2015. In the Scopus database there are seven journals devoted only to this topic. However, Google Scholar database contains 56,000 publications since 2015 and 1,180,000 publications in total.

The concept of "project management" includes two definitions, i.e. management and project, which often involves the main pillars of management in the definition of project management. Examples are the definitions of project management proposed by M. Radujković and M. Sjekavic (2017, p. 608), or A. Karbownik. According to the first authors, project management refers to "planning, organisation, monitoring and control of all aspects of project, with motivation of all included to achieve project goals on safe manner, within agreed schedule, budget and performance criteria". A. Karbownik (2017, p. 17), however, considers project management to be "the implementation of specific activities by planning, organising, motivating and controlling those leading to the achievement of the project objective, using the available resources". W. Walczak, on the other hand, accentuates the process of project management by defining it as a sequential process of making decisions relating to project resources and tasks. Other scientific researchers, such as R. K. Wysocki (2013, p. 68) refers to the definitions adopted in project management standards and methodologies.

The following table (Table 3) presents the project management definitions adopted by organisations and associations developing standards and methodologies in this area. The classical approach (known as cascade or waterfall) is mainly represented by PMBoK and Prince2 (Krysiak, Głowania, p. 82). In an Agile approach Polish entrepreneurs utilise mainly SCRUM, TDD (Test-Driven Development) and less frequently DSDM (Spałek, pp. 162-163), (Liebert, p. 281). It should be mentioned that currently agile approaches are not only the domain of IT companies, the development of the industry 4.0 concept has resulted in adaptation of agile approaches to project management also by companies from other industries (Spałek, 2017, p. 109).

Table 3.

Selected definitions of project management

\begin{tabular}{|c|c|c|}
\hline \multirow{2}{*}{$\begin{array}{c}\text { Standard/Methodology/ } \\
\text { Approach }\end{array}$} & \multicolumn{2}{|c|}{ Definition } \\
\hline & project management & Project \\
\hline $\begin{array}{l}\text { Project Management } \\
\text { Institution (PMI) }\end{array}$ & $\begin{array}{l}\text { "the application of knowledge, skills, } \\
\text { tools and techniques to project activities } \\
\text { to meet the project requirements" }\end{array}$ & $\begin{array}{c}\text { "a temporary endeavor undertaken to } \\
\text { create a unique product, service, or } \\
\text { result" }\end{array}$ \\
\hline $\begin{array}{l}\text { Projects In Controlled } \\
\text { Environments (Prince2) }\end{array}$ & $\begin{array}{l}\text { "the planning, delegating and control of } \\
\text { all aspects of project, and the motivation } \\
\text { of those involved, to achieve the project } \\
\text { objectives within the expected } \\
\text { performance targets for time, cost, } \\
\text { quality, scope, benefits and risk" }\end{array}$ & $\begin{array}{l}\text { "a temporary organisation that is created } \\
\text { for the purpose of delivering one or } \\
\text { more business products according to an } \\
\text { agreed business case" }\end{array}$ \\
\hline
\end{tabular}


Cont. table 3.

\begin{tabular}{|c|c|c|}
\hline $\begin{array}{c}\text { International Project } \\
\text { Management Association } \\
\text { (IPMA) }\end{array}$ & $\begin{array}{c}\text { "concerned with the application of } \\
\text { methods, tools, techniques and } \\
\text { competences to a project to achieve } \\
\text { goals" }\end{array}$ & $\begin{array}{l}\text { "a unique, temporary, multidisciplinary } \\
\text { and organised endeavour to execute } \\
\text { agreed deliverables within predefined } \\
\text { requirements and constraints" }\end{array}$ \\
\hline $\begin{array}{c}\text { Open Project } \\
\text { Management } \\
\text { Methodology }\left(\mathrm{PM}^{2}\right)\end{array}$ & $\begin{array}{l}\text { "the activities of planning, organising, } \\
\text { securing, monitoring and managing the } \\
\text { necessary resources and work to deliver } \\
\text { specific project goals and objectives in } \\
\text { an effective and efficient way" }\end{array}$ & $\begin{array}{c}\text { "temporary organisational structure } \\
\text { which is setup to create a unique product } \\
\text { or service (output) within certain } \\
\text { constraints such as time, cost, and } \\
\text { quality" }\end{array}$ \\
\hline ISO 21500 & $\begin{array}{c}\text { "the application of methods, tools, } \\
\text { techniques and competencies to a } \\
\text { project" }\end{array}$ & $\begin{array}{l}\text { "a unique set of processes consisting of } \\
\text { coordinated and controlled activities } \\
\text { with start and end dates, performed to } \\
\text { achieve project objectives" }\end{array}$ \\
\hline $\begin{array}{l}\text { Association for Project } \\
\text { Management (APM) }\end{array}$ & $\begin{array}{l}\text { "an iterative and incremental approach } \\
\text { to delivering requirements throughout } \\
\text { the project life cycle" }\end{array}$ & $\begin{array}{c}\text { "produces and delivers work in short } \\
\text { bursts (or sprints) of anything up to few } \\
\text { weeks" }\end{array}$ \\
\hline
\end{tabular}

Source: own elaboration based on PMI, p. 10; Prince 2, p. 8, 10; IPMA, p. 36; PM², p. 5, 7; ISO 21500, p. 3-4; www.apm.org.uk.

In the project management definitions outlined above, it is critical that the project requirements are met/achieved, which is expressed both by PMI and IPMA, PM² (methodology developed for the management of European projects by the European Commission) and APM. Another essential element of project management is the necessity to use proper tools, techniques and knowledge/competences that will contribute to achieving the planned objectives. Both Prince 2 and $\mathrm{PM}^{2}$ refer to the definition of management and emphasise planning, organisational and control aspects. In most cases, the proposed definitions of a project focus primarily on its temporality (PMI, Prince2, IPMA, $\mathrm{PM}^{2}$ ) and then on the uniqueness of the products it delivers (PMI, $\mathrm{PM}^{2}$ ) or the implemented set of processes (ISO).

Several approaches to project management, such as SCRUM, Six Sigma or AgilePM by DSDM (Dynamic System Development Method - currently Agile Business Consortium) use the concept of project management and project in their official materials, but do not define them. Therefore, it can be concluded that in the Agile Project Management approach the definitions available in waterfall approaches are followed. This is also supported by the fact that in the case of Prince2 or PMI there are two approaches to project management Agile and Cascading.

None of the mentioned definitions of project management or the project itself referred to the company's strategy, social, environmental or even stakeholder impact. Moreover, stakeholders are one of the main reasons for the implementation of projects (stakeholder customer) and a key element taken into account in the creation of a project management plan and planning the project progression, e.g. by choosing an appropriate project stakeholder management strategy. A stakeholder can therefore be the first link in the line of CSR and project management. It should be emphasised that project management (in other words - how to lead 
projects) is not a company strategy on its own, however, projects may constitute its key element. Then, where should the link between CSR and projects be sought?

In project management, the company's strategy, which is directly referring to the definition of CSR, appears only at the project portfolio stage. Through PMI, the portfolio is defined as "project, programs, subsidiary portfolios, and operations managed as a group to achieve strategic objectives". According to B. Sorychta-Wojsczyk, one of the potential ways of implementing the company's strategy is to directly transfer it to current operations and a set of properly defined projects and programmes (in other words - a project portfolio). Project portfolio management refers to the strategic objectives of the company's operation (Bilgin, et al., 2017, p. 357), in which CSR should already be incorporated. Project portfolios (including current activities, programmes and projects according to PMI) must be correlated with the company's strategy, ensure its implementation and provide opportunities for future development of the company. However, as A. Kozarkiewicz emphasises, the project portfolios already implemented may affect the choice of an appropriate strategy and its direction.

\section{Conclusion}

Corporate Social Responsibility is a widespread concept described in the literature on the subject, which has been regulated by law, e.g. in the Directive of the European Parliament and of the Council regarding the disclosure of non-financial information, or in the Act of 15 December 2016 which amended the Accounting Act. However, it is not uncommon for CSR to be incorporated into the aspect of project management. The analysis of the definitions of "project management" and "project" demonstrates a lack of direct correlation with CSR, which, among others, is perceived as a business management strategy taking into account its impact on society, environment and stakeholders. At this point, the only link in the line of CSR and projects seems to be the stakeholders. Empirical studies conducted in this matter should therefore consider the degree of impact of other areas of CSR (such as: taking care of social interest, environmental welfare and sustainable development) on both the project itself and its management.

The comparison made between 'CSR' and the term 'portfolio management' already indicates a greater correlation between these concepts. In both cases, the definitions of these terms refer to the company's management strategy, i.e. they are planned at the highest level of management of the organisation. It may therefore be assumed that the place of Corporate Social Responsibility is in the portfolio management and involves planning and implementation of current activities, programmes or projects relevant to the company's strategic objectives and taking into account their impact, as well as the impact of the company itself on CSR areas. It seems, however, that taking into consideration only the area of stakeholders to be able to talk 
about the social responsibility of the project is not enough. Definitions of CSR usually refer to at least three areas - stakeholders, society and the environment. It means that the portfolio itself may contain projects, programmes, or activities thematically focused on three areas of CSR, or include in their structure packages of works targeted at them.

\section{References}

1. Bilgina, G., Ekena, G., Ozyurta, B., Dikmena, I., Birgonula, M.T., Ozorhon, B. (2017). Handling project dependencies in portfolio management. Science Direct, Procedia Computer Science, 121.

2. Bowen, H.R. (1953). Social Responsibilities of the Businessman. New York: Harper \& Row.

3. Buczkowski, B., Dorożyński, T., Kuna-Marszałek, A., Serwach, T., Wieloch, J. (2016) Społeczna odpowiedzialność biznesu. Studia przypadków firm międzynarodowych. Łódź: Wydawnictwo Uniwersytetu Łódzkiego.

4. Council for Six Sigma Certification (2018). A Complete Step-by-Step Guide. A Complete Training \& Reference Guide for White Blests, Yellow Belts, Green Belts, and Black Belts. Buffalo.

5. Czubała, A. (2016). Corporate social responsibility in marketing. Forum Scientiae Oeconomia, 4, 1.

6. Dyrektywa Parlamentu Europejskiego i Rady 2014/95/UE z dnia 22 października 2014 r. zmieniająca dyrektywę 2013/34/UE w odniesieniu do ujawniania informacji niefinansowych i informacji dotyczących różnorodności przez niektóre duże jednostki oraz grupy, D. Urz. UE L 330/1 z dnia 15.11.2014.

7. European Commission. $P M^{2}$ Project Management Methodology Guide - Open Edition. Avaliable online www.publications.europa.eu, 10.08.2019.

8. Goergen, M., Chahine, S., Wood, G., Brewster, C. (2019). The relationship between public listing, context,multi-nationality and internal CSR. Journal of Corporate Finance, 57.

9. Hamidu, A., Haron, H., Amran, A. (2015). Corporate Social Responsibility: A Review on Definitions, Core Characteristics and Theoretical Perspectives, Mediterranean Journal of Social Sciences, 6, 4.

10. Hope, E. (2017). Modele relacji między corporate social responsibility a public relations, Studia Ekonomiczne. Zeszyty Naukowe Uniwersytetu Ekonomicznego w Katowicach, 313.

11. Internationat Project Management Associate (2015). Individual Competence Baseline for Project, Programme \& Portfolio Management. Version 4.0. Nijkerk: IPMA.

12. ISO 26000. Guidance on social responsibility. Avaliabe online www.pkn.pl, 22.07.2019.

13. ISO21500 (2012). Guidance on project management. Geneva: ISO copyright office. 
14. Karbownik, A. (2017). Zarządzanie projektami w przedsiębiorstwie. Gliwice: Wydawnictwo Politechniki Śląskiej.

15. Klimek, J. (2014). Etyka biznesu. Teoretyczne założenia, praktyka zastosowań. Warszawa: Difin.

16. Komunikat Komisji Europejskiej, Odnowiona strategia UE na lata 2011-2014 dotycząca społecznej odpowiedzialności przedsiębiorstw (2011).

17. Kozarkiewicz, A. (2012). Zarzadzanie portfelami projektów. Wdrażanie i monitorowanie strategii organizacji za pomoca projektów. Warszawa: PWN.

18. Krysiak, M., Głowania, S. (2017). Metodyki zarządzania projektami IT i ich ryzykiem: przegląd i wykorzystanie. Studia Ekonomiczne. Zeszyty Naukowe Uniwersytetu Ekonomicznego w Katowicach, 340.

19. Latoszek, E. Proczek, M., Krukowska, M. (eds.) (2016). Zrównoważony rozwój a globalne dobra publiczne $w$ torii $i$ praktyce organizacji międzynarodowych. Warszawa: Dom Wydawniczy Elopsa.

20. Leoński, W. (2016). Narzędzia społecznej odpowiedzialności biznesu a wielkość przedsiębiorstwa. Studia Ekonomiczne. Zeszyty Naukowe Uniwersytetu Ekonomicznego w Katowicach, 254.

21. Levytska, G., Wrzesińska-Kowal, J. (2013). Społeczna odpowiedzialność biznesu w działalności przedsiębiorstw gastronomicznych w Polsce. Zeszyty Naukowe SGGW w Warszawie. Ekonomika i Organizacja Gospodarki Żywnościowej, 103.

22. Liebert, F. (2017). Zarządzanie projektami w przedsiębiorstwach branży IT - studium literaturowe. Zeszyty Naukowe Politechniki Ślaskiej. Seria: Organizacja i Zarządzanie, 101.

23. Misztal, A. (2016). Raport społeczny jako narzędzie zarządzania CSR. Studia i Prace WNEiZ US, 43/1.

24. Nicholas, J.M., Steyn, H. (2012). Zarzadzanie projektami. Zastosowania w biznesie, inżynierii i nowoczesnych technologiach. Warszawa: Oficyna a Wolters Kluwer business.

25. Pisani, N., Kourula, A., Kolk, A. (2017). How global is international CSR research? Insights and recommendations from a systematic review. Journal of World Business, 52, 5.

26. Prince 2 (2017). Managing Successful Projects with Prince2. Norwich: The Stationery Office.

27. Project Management Instytutuin (2017). A Guide to the project management Body of Knowledge. PMBOK GUIDE. PMI.

28. Radujković, M., Sjekavica, M. (2017). Project Management Success Factors. Procedia Engineering, 196.

29. Responsible Business Conduct. First National Action Plan for the United States of America. Available online https://2009-2017.state.gov/e/eb/eppd/csr/naprbc/265706.htm or https://2009-2017.state.gov/, 12.08.2019. 
30. Rojek-Nowosielska, M. (2017). Definicja CSR według normy ISO 26000 a praktyka gospodarcza. Ruch Prawniczy, Ekonomiczny i Socjologiczny, 3.

31. Rong-Jia, SU, Xiao-Wen, JIE, Literature Review on Corporate Social Responsibility, International Conference on Management Engineering and Management Innovation (ICMEMI 2015). Available online www.atlantis-press.com/proceedings/icmemi-15/16175, 22.07.2019.

32. Różańska, E. (2015). Integracja standardów raportowania społecznej odpowiedzialności przedsiębiorstw. Studia Oeconomica Posnaniensia, 3, 1

33. Schwaber, K., Sutherland, J. (2017). The Scrum Guide. The Definitive Guide to Scrum: The Rules of the Game. Available online www.scrumguides.org, 10.08.2019.

34. Sorychta-Wojsczyk, B. (2013). Strategia a zarządzanie portfelem projektów w jednostkach samorządu terytorialnego - studium literatury. Zeszyty Naukowe Politechniki Ślaskiej. Seria: Organizacja i Zarzązanie, 63.

35. Spałek, S. (2016). Doskonalenie zarządzania projektami w przedsiębiorstwie. Management Forum, Publishing House of Wroctaw University of Economics, 4, 2.

36. Spałek, S. (2017). Zarządzanie projektami w erze przemysłu 4.0. Ekonomika i Organizacja Przedsiębiorstwa, 9(812).

37. Spałek, S. (2018). Rozpoznawalność i stosowanie zwinnego zarządzania projektami w polskich przedsiębiorstwach w świetle badań empirycznych. Studia i prace Kolegium Zarządzania Finansów, Zeszyt Naukowy, 159.

38. Tylec, A. (2016). Społeczna odpowiedzialność biznesu w zarządzaniu przedsiębiorstwami w Polsce - synteza badań. Zeszyty Naukowe Politechniki Śląskiej, Seria: Organizacja i Zarzadzanie, 97.

39. Ustawa z dnia 15 grudnia 2016 r. o zmianie ustawy o rachunkowości (Dz.U 2017, poz. 61).

40. Ustawa z dnia 2 lipca 2004 r. o swobodzie działalności gospodarczej (Dz.U. 2004, poz. 1807).

41. Walczak, W. (2010). Rola fazy planowania w zarządzaniu projektami. E-mentor, 1(33). Available online http://www.e-mentor.edu.pl/artykul/index/numer/33/id/709, 22.07.2019.

42. Wysocki, R.W. (2013). Efektywne zarzadzanie projektami. Tradycyjne, zwinne, ekstremalne. Gliwice: Wydawnictwo Helion. 